\title{
Reviewing family studies: a brief comment on selected topics ${ }^{\star}$
}

\author{
Maria Carolina Tomás ${ }^{* *}$
}

In the face of changes in the family and of academic concerns that have become evident in the study of the influence of such changes, the data collecting and theoretical framework used in family research deserve close attention. In this paper I review briefly some important international contributions to the field of family studies and point out challenges and still unanswered questions for future research in Brazil. The three main topics treated here are: 1) changes in the concept of family; 2) women's, and especially mothers', presence in the labor market (income, job opportunities, hiring preferences, etc.) and, more specifically, the transformation of the discussion from the working woman to the working family; and, 3) the influence of both these aspects on child rearing. At the end of the paper I reinforce previous research suggesting improvements in projects for collecting data. On the theoretical side I highlight the importance of three frameworks. First, the economic aspect of social action is not the only factor effecting how people make decisions in the family sphere. Second, there is need to revise the theory of the Second Demographic Transition approach, especially regarding migration and mortality and their relationship to family. Third, there is need for greater integration among demographic studies, gender studies, and feminist theories.

Keywords: Family changes. Children's outcomes. Women and working families.

\footnotetext{
* I am grateful to Professor Michael Hout for our discussions about the family in the United States and for reading and commenting on my first reflections in the field that later became this paper. I also wish to thank the two anonymous reviewers who gave important contributions to the discussion and Flávia P. Xavier for reading and commenting on my last draft before resubmitting.

** PhD in Sociology and Demography from University of California, Berkeley, and substitute professor for the Department of Demography at the Regional Development and Planning Center (Cedeplar) at Universidade Federal de Minas Gerais (UFMG) (mctomas@berkeley.edu).
} 


\section{Introduction}

Family is a very important topic of study in the social sciences. Topics such as marriage, divorce, parental influence on children's outcome, and female labor force participation and its effects on family life are common objects of analyses. In this paper, I briefly review some important international contributions to the field of family studies, contextualize the discussion in Brazil, and point to some challenges and still unanswered questions for future research in Brazil. Therefore, my objective here is not to extensively discuss each topic, but to motivate other researchers to focus more attention on studying the family in order to answer these and other questions, and produce more appropriate data for our analyses.

There have been at least three important changes in the family in recent decades: an increase in divorce rates, an increase in single-parent families, and an increase in women in the labor force, especially mothers. Great efforts have been made to understand how these changes may affect different areas, including the concepts of family, women's labor market outcomes, and the relationships between changes in families (i.e. increased hours mothers spend away from home and single parenting) and children's outcomes. In this essay, I discuss these three topics, which have also been treated in numerous other studies on the family.

The main challenges for discussing these topics are, first, to obtain appropriate data for dealing with the changes in family structure and meanings, and, second, to incorporate a more suitable theoretical framework. One of the important contributions of the field of demography is the discussion on the Second Demographic Transition (SDT). This discussion focuses not only on the dynamic of demographic components but also, and especially, on differences in behavior toward family formation (new arrangements, increased cohabitation, and late marriages, for example), family dissolution (increased divorce rates), and slower transition to adulthood (LESTHAEGHE, 1997, 2007). The SDT represents a great ideational change that influences the size, form, and composition of families.

It is important to consider ideational changes when deciding how we should conceptualize and study the family and how we should discuss women, and especially mothers, in their labor force participation and their children's life outcomes. We need to question whether the data and the theoretical framework are still sufficient and appropriate for the analysis. Therefore, I intend to discuss these three topics - naming the concepts of family, children's outcomes, and women's outcomes in the labor market and their consequences on children and family life - then raise some unanswered questions for Brazil and discuss important challenges in data and methodology that we face in studying the family.

The article is divided into five sections. The first section is this brief introduction, the following section discusses the concept of family, and the third part approaches what I call the transition from working women to working families. The fourth section presents studies and suggestions for research on families' and parents' influence on children's outcomes. In the last part, I conclude by summarizing problems in data collection and point out a few 
important theoretical frameworks that should be considered in family studies. I also highlight topics that have not been sufficiently explored in family research in Brazil.

\section{The concept of family}

In this section I focus on two questions: (1) What is family? and (2) Do changes in the family represent a real rupture from what was considered family or an ongoing process of change but without losing the main characteristics of family relations? The answers to the second question are intimately related to the concept of family that is adopted in the study. Moreover, this discussion is quite similar to the debate on the Second Demographic Transition because in this framework there is also a question as to whether the changes in the family, especially in fertility, have characterized a new transition or are merely a continuation of the First Demographic Transition (i.e.: CLIQUET, 1991; COLEMAN, 2003, 2004).

Although family is a central research topic in the social sciences, definitions of it may vary. For Bongaarts (2001, p.263), "[t] he family and the household are the most fundamental socioeconomic institutions in human society. The principal social function of the family is to bring children into the world and to care for them until they can support themselves." He continues by stating that family is a sphere that balances resources across generations. Therefore, family is a solution for the fact that, during their lifetimes, everyone has a sequence of net consumption (during childhood), net production (during adulthood) and, again, net consumption (during old age). The solution takes the form of implicit contracts that are built into marriage and parenthood and that are enforced by social control.

In empirical research, especially surveys, the family is usually defined as a group of persons related by blood, marriage, or adoption and living in the same residence $B \cup R C H$, 1979; BONGAARTS, 2001; TILLMAN; NAM, 2008). This definition is basically synonymous with the nuclear family. Some researchers find the definition limited and problematic because it does not reflect all the real potential resources involved, such as occasional economic support for children from a non-resident parent or economic help for elders that live alone, all of whom may be family members.

Tillman and Nam (2008) noted the limitations of the standard definition of family. Analyzing data for the Netherlands, these authors showed that family size and composition change according to the definition of family. They presented three definitions: (i) a standard residence-based definition, that is, a relationship based on blood, marriage, adoption, and co-residence; (ii) an expanded residence-based definition, which includes cohabiting spouses and their children; (iii) and a broader non-residence-based definition, which expands the definition even further to include non-resident spouses and children. The results suggest the inclusion of persons other than nuclear family members in the analysis. As the authors highlighted, this factor is important for public policy formulation.

Lloyd and Desai (1992) investigated variations in living arrangements. They focused on children's experience living with their mother, father, and siblings and on households with 
multiple generations, in 19 developing countries. They concluded that, contrary to some expectations, in many countries of sub-Saharan Africa and Latin America, as opposed to parts of Asia and North Africa, children spend a substantial proportion of their childhood years apart from one or both parents and, by extension, apart from at least some of their siblings. In addition, a significant number of children, particularly in sub-Saharan Africa, receive support from adults other than their parents.

Similarly, Bengtson (2001) proposed that family analysis should go beyond the definition of the nuclear family. He focused on multigenerational relationships and suggested that these relationships are more important in the 21st century because of several factors, such as i) changes in population aging, which result in "longer years of shared lives" among persons of different generations; ii) the increasing importance of grandparents and other relatives in fulfilling family functions; and iii) the strength and resilience of intergenerational solidarity over time. In relation to Bengtson's (2001) first factor, Watkins et al.'s (1987) work showed that despite declining fertility and higher divorce rates, women in the 1960 and 1980 cohorts spent more years in marriage and as parents than did women from earlier generations. They also spent more years as children of aged parents.

Mare (2011) highlighted the importance of considering multigenerational ties in social science research. Grandparents' resources, for example, can influence grandchildren's well-being and future outcomes, as these younger individuals are directly influenced by previous generations' resources. In addition, multigenerational relations influence population reproduction. As Mare highlighted, multigenerational influence also operates through the demographic process, meaning differential fertility, survival, migration, and marriage patterns. His approach focuses on intergenerational mobility, but one can expand this view to other studies, especially in Brazil, where there has been very little discussion regarding the role of previous generations other than parents regarding inequality and poverty.

There are, therefore, different concepts of and approaches to family, each having a different operationalization. They are also influenced by the available research resources, especially available data.

\section{Methodological issues and the concept of family}

The definition of family, its composition, and its size are important features for social research and public policy orientation. Whether and how cohabiting couples, same sex couples, and nonresidential members are considered may influence results, especially in studies on children's outcomes and household composition. In addition to definitions of the family, studies in this field face other important methodological difficulties, such as defining head of household, defining children and youth, and determining the differences between household and family.

Defining head of household is far from trivial because it is culturally influenced. It especially depends on gender roles because, in more traditional societies, people are more 
likely to report the man as the head of the household. In addition, the question is usually self-declared, meaning that the respondent can use any criteria at all for reporting who the head of the household is. Therefore, different persons may define the head of the household differently, since some might refer to the individual with the highest income whereas others may indicate the person who carries the most weight in making decisions in the household.

Another methodological issue is the definition of children. Bongaarts (2001), for example, considered children to be individuals who are age 18 or under, whereas Lyod and Desai (1992) consider children to be individuals under the age of 15. In Brazil, children are defined as individuals aged 14 or under. Some studies divide the group into ages 0 to 7 and 8 to 14 .

Defining youth is also a topic of discussion. Youth are defined as individuals between the ages of 15 and 29 (VIEIRA, 2008). This definition is far from trivial because, although age is not the only factor for defining transitions in life, the use of different age ranges can influence results for studies on whether and how the transition to adulthood is changing. These changes are very important for understanding modifications in the processes of family formation, such as marriage timing and decisions about having children.

On the other hand, given the available data and the research question, authors may select different age groups. Vieira (2008), for example, selected points that mark the transition to adulthood. She determined a wide age range, ages 13 to 44, to be able to identify the actual point that marks the transition. Tomás et al. (2008), on the other hand, selected individuals between ages 15 and 24, because these authors wanted to include parental characteristics, and after age 24 children are more likely to have already moved out of their parents' home (TOMÁS, 2007). Although these two studies were motivated by different questions, there is agreement that the transition occurs between the ages of 20 and 24.

Another important observation is related to the difference between family and household. Depending on the definition of family that one uses, there may be more than one family in a household. Household is usually defined as a group of persons (or one person) who make common provisions for food, shelter, and other essentials for living. According to the United Nations (1980), family is defined as the members of a household who are related by marriage, blood, or adoption (BONGAARTS, 2001). This is the classic definition of the nuclear family.

One important piece of evidence to indicate that household and family are different is the relationship between the proximate determinants of household size (fertility, age at marriage, divorce, adoption, nuptiality, mortality, and migration) and the number of members in a household and in a nuclear family. Bongaarts (2001) found that fertility, age at marriage and proportion of heads of household living without a spouse explain only $59 \%$ of the variation in average household size in selected developing countries, whereas this factor explains $81 \%$ of the variation in average family size. This difference occurs because many households in developing countries include non-nuclear members.

In Brazil we usually consider family as persons living in the same household and related by marital union (formal or informal), biological parenting, or adoption by at least one of the spouses. Even when there is information about more than one family living in the household, 
most studies use only the first family or consider each family as independent of the other. Because there are no data on biological parents, it is assumed that children who live with a family are biologically related to or adopted by at least the head of household or his/her spouse. Some potential problems in this approach are the exclusion of children living in different households, the attribution of characteristics of stepparents to children, and the exclusion of characteristics of parents who live in other households. These problems tend to be greater when studying contemporary families because of the increased divorce rates and single parenting. Another issue is considering different families living in the same household as being independent of one another, although they may be related by blood and co-residing. They may even share resources and help each other in fulfilling family functions.

In the Demographic Censuses, the Demographic Health Survey (DHS) and the Pesquisa Nacional de Demografia e Saúde (National Demographic and Health Survey) (PNDS), the marital status of respondents, whether formal or informal, can be identified. But these surveys provide no information about the father of the children and whether the male spouse living in the household is their biological father or stepfather. When using the Pesquisa Nacional por Amostra de Domicilios (National Sample Household Survey) (PNAD), except for the years between 1992 and 1995, and for 2009, family structure is even more uncertain because there is no information about the type of relationship of the head of the household with her or his spouse. It is only assumed that they are in some type of union (it is unknown whether the union constitutes cohabitation or marriage), and that they are the parents of the children living in the household. These data are becoming more and more difficult to use, in view of the changes that families are undergoing today (rising divorce rates, single parenthood, and the importance of other relatives). It is worth highlighting that, in 1996, the Brazilian Statistics Bureau (Instituto Brasileiro de Geografia e Estatística) (IBGE) stopped asking about marital status in the PNADs, but this variable returned in 2009.

\section{Is the family in trouble?}

Even without an agreement on the definition of family, most researchers argue that the family is in trouble or is at least changing. The changes most often discussed (and I would say mostly agreed upon) are the increases in female labor force participation, divorce, cohabitation, and single parenthood rates.

One of the explanations for these changes is the fact that low-income male high-school graduates are increasingly having to take on lower paying jobs and are therefore becoming less interesting to females. Thus, women, especially those with low levels of education, are more motivated to stay single than to marry. In addition, higher public welfare benefits may also help to explain the increase in single motherhood. Another factor consists of the overall reductions in the advantages of marriage due to a decline in specialization, since more women are working outside the home. More independent women reflect increased singlehood and higher divorce rates (BECKER et al., 1997). 
Another possible explanation consists of changes in the meaning of marriage (EDIN; KALAFAS, 2005; CHERLIN, 2009). Marriage has become an expression of self-realization whereby couples are expected to go through a series of steps leading to marriage, which can be considered a capstone. The change in the meaning of marriage may also explain the greater numbers of divorces. As marriage gradually became a space for self-realization, individuals in relationships that fail to contribute to their self-development are now more likely to leave them. Lastly, changes in normative expectations also help explain current changes, as there is now greater acceptance of non-marital co-residence, single parenthood, and stepfamilies. Individuals are no longer excluded from their social circles because of taboos related to family.

Another question related to family difficulties is whether the changes are new or a continuation of a previous process. Bumpass (1990) argues that these changes are a continuation of earlier changes that occurred as the result of secularization and modernization. Fischer and Hout (2005) argue that many family "troubles" are not as problematic as they would have been in earlier times. For the authors, the greatest demographic changes occur among the elderly as they have greatly influenced the increase in the percentages of people living alone. In contrast, much discussed matters such as family dissolution and family intimacy remained much more stable.

Fischer and Hout (2005) divided the changes into three groups. The first group includes major changes: the change in the proportion of persons living alone, the decrease in the birth rate, and the increase in female labor force participation. The second group consists of modest changes: the change in age at marriage, the higher divorce rate, the longer period before marriage, and increased cohabitation. The third group encompasses changes considered minor or minimal: the continuing value of both marriage and children, the fact that most Americans (about 90\%) eventually marry, and tolerance for extramarital sex. Therefore, some of the changes that are identified as new are actually continuations of gradual changes.

Many of the changes discussed by several authors must be contextualized. Fischer and Hout (2005) highlighted that in order to talk about "troubles" in the family, we must specify for whom, and when, the changes occurred. As far as for whom, Fischer and Hout brought up the example of the increase in the numbers of persons living alone. Although many analyses claim that this increase is due to greater numbers of single persons, for example, these authors showed that a great part of the increase in persons living by themselves is due to greater numbers of widows, resulting from lower death rates. Similar observations have been made regarding Brazil (i.e.: BERQUÓ, 1989; GOLDANI, 1993; CAMARANO et al., 2009). Some have also noted that the main change in family dissolution is that, in the past, it was more often due to death, wars, economic dislocations and infertility (external events), whereas today families dissolve due to choices and changes in values and options. This is a very important point for research on the Second Demographic Transition because it shows that the main change was ideational, involving trends in the area of cultural norms. As far as when the changes occurred, Fischer and Hout (2005) state that the turning point was between 1950 and 1960 . 
Goldscheider and Bures (2003) also approached the questions of changes for whom and when in a different analysis. They showed that there was a racial crossover in terms of the numbers of adults living in complex families. This crossover demonstrates that, in the past, blacks were more likely than whites to leave home and marry at young ages and were less likely to co-reside with other family members at older ages. The fact that, young black adults are now more likely than their white counterparts to live in complex families is not due to an increase in family complexity among blacks, but rather due to a rapid decrease in the number of young white adults living in complex families. The authors also discussed that the higher level of family complexity among blacks in the United States is both a relatively new phenomenon and one that is not limited to single-parent families; it characterizes people of all ages, those with and without children, and men as well as women. As far as when the crossover took place, Goldscheider and Bures estimated that it was in about 1950.

Another important point for consideration when analyzing the family "crisis" is the concept of the nuclear family. Besides the potential problems involved in terms of family living arrangements, as pointed out in this section, Bengtson (2001) called attention to two considerations that might come up in discussions on the family. First, there is an expected decrease in household size and household complexity and a convergence to nuclear families as society becomes more industrialized and more modern. This expectation might not be happening in modern society because of increasing diversity in family structure and the family's functions. For Bengtson, families are changing and becoming more diverse, expanding beyond the concept of the nuclear family and involving a variety of kin and non-kin relationships.

Bongaarts (2001) was also interested in the validity of the concept of the nuclear family. He analyzed whether developing countries are converging to the nuclear family, but he failed to find a consistent trend in this direction. Durham (1982) raised a different perspective. For her, the different family arrangements in society cannot be interpreted as cultural changes. She sees them rather as adjusted forms of the role model (nuclear family) in order to fill specific demands in society. Therefore, this author does not see the emergence or the increase in different types of families as indicators of a family crisis.

Bengtson's (2001) second point is the fact that changes in the family do not mean that this institution is in danger of devaluation or extinction. This point is very important because, given the existence of the variety of family structures in contemporary society, strictly defining family as the nuclear family could increase the likelihood of considering that the institution is in trouble. Therefore, Bengtson (2001) proposed that family relationships across several generations are becoming ever more important (as already discussed) and, in this sense, the "family decline" hypothesis is limited by its concentration on the family as a co-resident household and the nuclear family as its primary representation.

Therborn (2006) analyzed changes in the family during the period between 1900 and 2000 considering all parts of the world. He concludes that the sexual revolution was not worldwide, and the changes in the family are not necessarily evolutionary. He highlights that 
some of what are now termed "new behaviors" were common in Europe during the 19th century. Some new forms, or less frequent forms, became more common in 20th century, such as dual-income couples, couples without children, and elderly persons living alone. The main change for this author and for Durham (1982), who analyzed only Brazil, was the end of the patriarchy as the model family.

Analyzing the case of Brazil, Berquó (1989) asked whether the increase in urbanization and industrialization in Brazil would produce the same expectations and the same changes as were seen in more developed countries. She concludes that between 1970 and 1980 Brazil began showing family characteristics similar to those seen in more developed countries. For her, technological advances allowed people to both limit fertility and live longer, and this reality altered family size and structure. In addition, the feminist conquests influenced celibacy, age at first union, the type of union, and the duration and dissolution of relationships. For Camarano et al. (2009), the changes taking place in Brazil are along the same lines as those in the more developed countries, such as changes in size, form and composition of families, a trend that reflects a more individualistic view of the world.

On the other hand, it seems that the modernization of the family in Brazil does not mean a mass transition from an extensive family model to a nuclear family model, but the predominance of the nuclear family combined with a very frequent presence of other types of family (BILAC, 2006, p. 65). The possible explanations for this are: i) the economic instability of the majority of the population (BILAC, 2006; BERQUÓ; OLIVEIRA, 1992), who are unable to maintain their own households and are forced to live with relatives; ii) changes in the legislation, such as, the law which allowed divorce (BERQUÓ; OLIVEIRA, 1992; OLIVEIRA, 1996; GOLDANI, 2005); iii) migration, especially during the period of intense urbanization (BILAC, 1995); and iv) changes in family social norms, this last point having been discussed by all the authors mentioned above.

The role of legislation is emphasized by Goldani (1993), who states that there has been a change in the concept of family in the legislation. The Brazilian Constitution enacted in 1988 defines family as a stable relationship between a man and a woman. This new concept focuses on the need to protect family dependents, such as children, youth, and elderly people. In this sense, the Constitution recognizes the asymmetry of power among family members. Berquó and Oliveira (1992), and Oliveira (1996), focused on the role of legislation in increasing the number of separations and divorce. Although there is a recognition of the role of changes that have taken place in the legislation, all authors agree that cultural changes were the most important factor for transforming the family. They include the broader acceptability of non-marital sex, more women in the work force, fewer social stigma, and other factors (GOLDANI, 2005).

The role of economics is amply explored in Berquó and Oliveira (1992), where they analyze absolute marriage rates in Brazil in contrast to the economic situation during the 1980s, and found a decrease in marriage rates. A different emphasis is given by Bilac (2006), who concludes that the socioeconomic conditions of the majority of the Brazilian population are 
unstable, a factor that prevents the nuclear residence model to spread in Brazil as it did in Europe. Goldani (1993) also highlights the importance of solidarity among relatives for the family configuration in Brazil, especially among the poor. In contrast, for the middle class the existence of different family arrangements is due to the lack of satisfaction with the nuclear family as the model, following the logic of individualism.

It seems that although many authors treat the family as an institution at risk, others acknowledge that it is still important for most people. One point worth highlighting is that marriage has not lost its meaning. Bumpass (1990) says that virtually everyone plans to marry, and almost $90 \%$ are likely to do so. "Marriage is not going out of style, but it is being progressively delayed" (p.488). For Cherlin (2009), marriage has not lost its function and importance in society; it has changed its meaning: it became the "capstone," an expression of self-realization, and a space for individual development.

In the context of an increasing transformation in the family, Bumpass (1990, p.491) asks "Why is there still family?" His answer is that, The status our society ascribes to marital and parenting roles is eroding in comparison with those of the workplace, but the majority of us continue to find family roles intrinsically and uniquely rewarding." Relational aspects of family are not available at the marketplace, so the emotional fulfillment and the benefits of having a family make up for failings in other spheres of life. Therborn (2006), using Bilac's (2004) words, concludes that the sexual revolution did not decrease the desire for deep, longstanding, and exclusive emotional relationships. At the same time that there is a valorization of individualism, there is also a real dependence on family.

Finally, I want to discuss the implications and perspectives for Brazilian studies on the concept of family. To broaden our knowledge of changes in the family we must invest in two types of research. First we might aim at research on ideational changes, using the World Value Survey as a good source of data. Most studies in Brazil that use these data are in the area of political science (i.e. RIBEIRO, 2008; RIBEIRO; BORBA, 2010), or are analyses that focus on changes in values and their consequences regarding issues in Brazil (i.e. RIBEIRO, 2010). It is important to determine whether values, norms, and ideas regarding family are changing at the same pace that rates and proportions are. The second type of investment that must be made is in the area of data collection on family structure. One example is that analyses of cohabitation can count on only two sources of data in Brazil. One consists of the Federal Censuses, with the problem that the information is updated only every ten years. Other resources are the DHS and PNDS data but, unfortunately, these surveys contain very little information about spouses. For example, the 2009 PNAD results do not specify whether marital status is formal or informal.

Moreover, analyses of the meaning of cohabitation and its degree of equivalence to marriage are still incipient in Brazil. In most analyses, cohabitation and marriage are treated alike, but in some studies, analyses are separated by type of relationship (see, for example, LONGO; RIBEIRO, 2010; OLIVEIRA et al., 2005; MUNIZ; RIOS-NETO, 2004; LAZO; MORAES, 2004). One of the first works to treat cohabitation as the main object of analysis was Costa's 
(2004) dissertation. She used 2000 Census data to analyze factors associated with the probability that women between the ages of 15 and 84 will marry or cohabit. There have been many studies in the United States aimed at understanding the differences between formal and informal unions and at typifying cohabitation (see, for example, CASPER; BIANCHI, 2000; HEUVELINE; TIMBERLAKE, 2004). In Brazil there is lack of research on cohabitation as the main object of analysis, where its meaning would be explained and the potential differences among the different varieties of cohabitation could be used to explain other family issues, such as time of birth, number of children, and gender inequality.

Another important area of data regards marriage/union history. The available information on this issue is from the 1984 PNAD and examples of studies that used these data are Goldani (1989), Lazo (1991) and Miranda (1993). The main problem of these data is that they are out-of-date and are cross-sectional, meaning that they do not capture recent trends. Up-todate information of this type would enable better understanding of movements in and out of unions, remarriage patterns, and differentials of assortative mating between first, second, or higher-order unions. DHS and PNDS are also options for studying remarriage because they ask about whether respondents are in their first or a higher-order union. Moreover, the 1996 PNDS is the only nationwide research that investigated reproductive behavior and characteristics of a male sample (MARCONDES, 2006).

Changes in the family seem to have reached all classes, races, and other population sectors (CHERLIN, 2009). However, the changes might not be the same or might not have the same meanings for the poor as they have for the middle class. Goldani (1993) suggests there are differences between poor and middle-class populations. Moreover, Manning and Landale (1996) highlight the importance of ethnic differences that may be motivated by different cultural beliefs and traditions in family formation. We therefore also need data that will enable researchers to explore potential differences among groups.

The changes in the family structure and in how members share their time among parenthood, the labor market, and house work have affected women's lives, meaning their role in society, their labor market outcomes, and their children's outcomes. These are the topics of the following sections.

\section{The transformation from working women to working families}

As was seen above, the increase in female labor force participation has played an important role in changing the family. At least three discussions are germane to this issue. The first involves labor market outcomes for women, especially mothers, and specifically, whether they have different or the same income and opportunities as men. The second involves how the family, as a group, deals with and negotiates women's time and career aspirations. The third topic considers whether female work is direct (i.e. few hours spent at home) or indirect (i.e. increased divorce rates) in influencing children's outcomes. This last topic is discussed in the following section. 
Women, including mothers, have increased their participation in the labor force. However, they are far from having the same outcomes as men. Women have lower average incomes, are underrepresented in occupations with higher status, and face more difficulties in getting jobs and being promoted.

The mechanisms for these differences are still being debated. Are the differences due to gender or are they due mainly to marital and/or childbearing statuses? How should men and women be compared? Sewell et al. (1980) analyzed the mechanism of status achievement, comparing men and women. They concluded that women, on the average, have a higher status in their first full-time job, but they lose points (about 2) on Duncan's scale when comparing this first full-time job with their current occupation. On the other hand, men, after their first job, gain about nine points on the scale during their lifetimes.

The analysis also compared single, married and childless women with mothers who have one or more children. The results showed that only single and childless women gain occupational status between first and current jobs and maintain a rough parity in occupational standing with men. The authors highlighted that it is not enough simply to compare averages because occupational variability among women is lower than among men. Overall, women are underrepresented in the highest and lowest occupational statuses. It seems that the main "cause" for differences in men's and women's occupational statuses in their current jobs is whether or not they have children, and these differences increase with the higher number of children women have.

Sewell et al.'s analysis aggregated all men and did not separate single, married and childless men, and fathers in the comparison. Therefore, even accounting for differences in women's status, the groups are not fully comparable. It would be interesting to compare single men and single women, and fathers and mothers, in order to better access gender differences. Are fathers also penalized? Do single men show better outcomes than fathers in the same way that single and childless women show better outcomes than mothers?

Correll et al. (2007) contributed to this topic. They wanted to better understand the mechanisms that produce what they called the "motherhood penalty" in the labor market. They were interested not only in the wage gap but also in differences in the likelihood of being hired and promoted. Other outcomes of interest were perception of level of competence and level of commitment, ability, and evaluation. Conducting a laboratory experiment, they found that mothers received the lowest rates for all variables while fathers were better evaluated than single men, and single women received the highest scores. In order to validate these results, they also conducted an audit study, sending resumes and cover letters to (real) employers who were hiring for entry-level and mid-level marketing and business job openings at a large newspaper in the Northeastern United States. The results of this second method support the findings of the laboratory experiment: mothers were less likely to receive a callback than any other group. However, there was no evidence of a fatherhood bonus. Moreover, childless women were significantly more likely to receive a callback from employers than equally qualified childless men. 
The main conclusion of the study was that motherhood is perceived as a status factor, due to normative expectations of what it means to be a good mother and an ideal worker. Mothers are considered less competent and less committed to their jobs, and this mediates the relationship between motherhood as a status factor and lower labor market outcomes. These results stressed the importance of considering not only gender but also the family dimension when analyzing men's and women's wages, promotions and hiring processes.

Therefore, it is important to compare men and women who have the same marital and childbearing statuses. The authors highlighted that the laboratory experiment results in which women who were not mothers had the highest rates might be due to the participants having evaluated all candidates at the same time and having tried to compensate their discrimination against mothers by overrating women but not men. Another explanation, in a footnote and proposed by an anonymous reviewer, suggests that employers might perceive current fertility as a sign of future fertility and thus an apparent commitment to the labor market. However, the story could be different: due to normative expectations women without children might be more likely to have at least one than those who already have children. Women who have more than one child might have already come to the end of their fertility and have no intention of having more children. Mothers' age would also be an important consideration for reaching better conclusions.

One example of this type of work in Brazil is the analysis of Muniz and Rios-Neto (2004), which showed important income differences between persons in formal unions, and differences between single and married men and women. Kassouf and Senauer (1996) also considered female family status (head, spouse and children) and estimated wage equations for women between ages 16 and 71. They also found important differences in income, depending on women's family status.

While marital and childbearing statuses influence how people perceive the level of commitment of female workers, human capital and labor market investments may also affect family formation and, more specifically, the timing of first marriage and first child. Blossfeld and Huinink (1991) asked this question based on the "new home economics" approach. This perspective predicts that investments in education and careers delay women's decisions to marry and have children. The proposed alternative hypothesis is that family formation timing is defined on the basis of normative expectations toward young women.

Using data for Germany, Blossfeld and Huinink found that women's extended investment in human capital delays marriage and motherhood due to normative expectations that young women in school are not yet ready for these transitions. However, increasing career investments lead women to postpone having children, but not postpone getting married. Therefore, the new home economics hypothesis that women's continuous investment in their professional careers delays childbearing is supported, but the prediction that it delays marriage is not born out. The school and work spheres have different effects on family formation, and being married, and having children seem to be perceived differently by women in terms of how these two elements of family formation might affect the future of their careers. 
With these results in mind, one might ask the following questions: Are women concerned about their work? Are they concerned about how employers and co-workers are going to perceive their competence and job commitment? Are they concerned about struggling with the second shift? These are still unanswered questions in Brazil, where there has been little effort to disentangle pressures related to normative expectations from pressures deriving from investments in education and career.

Another issue related to normative expectations for women's/mothers' roles and the female labor market outcomes is the second shift. Hochschild and Machung (1990, p.192) and their research team separately interviewed both partners of about fifty couples. They documented that $80 \%$ of the interviewed men did not share in any household chores or childcare. She considers this lack of involvement in the domestic sphere to be a result of gender ideology and gender strategy. Gender ideology is defined as the "set of beliefs about men and women and marital roles,", whereas gender strategy is the combination of one's gender ideology and the emotional conflict between one's own gender ideology and the partner's ideology and actions. This imbalance usually results in emotional stress for both partners and in prioritization of the man's career. In this sense, therefore, women have lower labor market outcomes not because of discrimination in the labor market, but because of a lack of attachment to the labor force and lack of time to dedicate to their careers, as well as fatigue and, especially, the matter of time competition between work and family. Additionally, things tend to be harder when they have children. To cope with the second shift, many women simply do not have leisure time, and sleep less. This finding supports the time use studies discussed in Bianchi (2000) and Sayer et al. (2004).

In Brazil, Fontoura et al. (2010) showed that many improvements have been made in order to achieve more equality between women and men. However, women still spend much more time doing housework than men and little change has been noted. Mattingly and Bianchi (2003) also highlighted that despite gains toward gender equality in other domains, discrepancies persist in the experience of free time. This is not only a gender issue but also a class issue. A study about children's use of time in Brazil shows that working-class girls report doing more domestic chores than girls in the middle class. In both classes, more girls than boys do housework, and boys have more leisure time than girls. Therefore, the difference in the workload of household tasks seems to be a class differentiation among children (CARVALHO; MACHADO, 2006). Possible explanations may include 1) more gender equality in middle-class families and 2) the use of paid labor to do the housework for these families.

The solution proposed by Hochschild and Machung (1990) for balancing family and work is a "New Man", a husband who shares the housework and childcare, cares about his wife's job, and is open to negotiating his own career in order to have a better balance between work and family. The interesting point in this conclusion is that if the main mechanism for the motherhood penalty is normative (CORRELL et al., 2007), the decision as to whether to have a first child is not related to educational investment but to normative expectations and career investments. Marriage seems to be affected by neither human capital nor career investments 
(BLOSSFELD; HUININK, 1991), and given that the majority of men and women marry at some point in life and that most of them will also have children, this "New Man", not only at home, but also outside, might be very important for closing the gap between men's and women's wages, promotions, and hiring rates.

Finally, I want to discuss the title of this section: "The transformation from working women to working families." Why am I not using only the term working women? Because it has been shown that mothers and childless women are perceived as different types of workers and have different outcomes in the labor market. In addition, they are also distinct from fathers and childless men. Moreover, working families imply a more complex network of relationships, as demonstrated by Hochschild and Machung (1990). In this case both partners are involved in the "conflict" between work and family, and they must negotiate and reconfigure their gender ideologies and gender strategies in order to lead more balanced lives. Hence, today, analyses must consider the individuals' marital status and parenthood, in contrast to the first discussions on women's labor market outcomes, which concentrated on differences between men and women. Moreover, in the past, the challenge of balancing work and family was analyzed as being a women's "problem,", "whereas it has now become a potential family "problem," or at least an issue that involves more than one family member.

There has been little discussion about the dimension of gender as a social construction, and not only as a variable in empirical applications (see, for example, WATKINS, 1993; MACKINSSON, 1995; OLIVEIRA, 1996; BILAC, 1995, 2006; RILEY; MCCARTHY, 2006). As discussed in this section, the problem of balancing work and family is not only a women's issue, it is a family issue, where both spouses must negotiate their gender identities. Fatherhood, for example, is an important topic for research, especially regarding how men construct their identity as fathers in relation to their gender identity as men. Qualitative research would seem to be the best way to contribute to this discussion.

Moreover, there is a lack of appropriate data for treating the issue of working mothers and their decisions in terms of job and motherhood. Longitudinal data is very important for disentangling causality in the case analyzing work and motherhood and for identifying trends and changes over time. The use of experiments would also benefit this kind of research, taking Correl's (2007) study as an example. Experiments have much to contribute to the normative discussion, explaining why and how people make decisions.

One of the main discussions about the greater numbers of women, especially mothers, in the labor market, is how this all affects children's outcomes. Moreover, many researchers are also interested in how changes in the family structure affect children's achievements, and is the theme of the next section.

\section{Family changes and children's outcomes}

The changes in family discussed in the previous sections raise another set of questions regarding how the transformations in family structure and the greater presence of mothers 
in the labor force may affect children's outcomes and well-being (i.e. child mortality). In this section, I discuss an old research topic: how family/parental characteristics, such as time families spend together and employment status, influence children's outcomes. In some research there is great emphasis on mothers' influence, such as time spent with children. In contrast, some studies ignore this issue, such as traditional social mobility studies, where only the fathers' occupations are considered. In this section, I discuss the importance of considering parents' characteristics, including parents who may not be living in the same household as their children.

Many studies focus on the possible negative effects of mothers' work on children's cognition and well-being, due to the limited time they spend together. This issue is very important, as emphasized by Coleman (1988) in his approach to the creation of human capital, where he highlights the importance of child-parent interaction. Some evidence can be drawn from studies such as that of Lareau's (2003), which who emphasized the importance of conversations at home for language development and extensive reasoning in the middle class and the importance of fathers' involvement in single-mother families, as concluded by Beller (2006). However, the apparent problem of the lack of time seems not to be confirmed, as the study by Bianchi (2000) showed. The findings are that, in reality, mothers are working more in terms of salaried activities and spending the same amount of time, or even more, whit their children. One of the explanations is that, in the past, women spent more time doing housework and children spent more time with other family members, such as grandmothers or older siblings. Another explanation is that today, mothers seek ways to maximize their time with their children.

Other very important issues related to Bianchi's (2000) argument regarding family transformations include children's needs and changes in the involvement of fathers over time. For example, children nowadays spend more time at school than in the past and fathers' time with their children has increased, a factor that might help explain why the time mothers spend working may not negatively affect children's outcomes. Even more relevant is Bianchi's acknowledgement that mothers do what they can to avoid compromising their time with their children by working part-time, taking periods off from work, sleeping less, or having less leisure time than unemployed mothers. Lareau (2003) reinforces this point through examples of parents' efforts: parents work but after work they do what they can to be part of their kid's life. to. In addition, the number of years that married women with younger children (under 6 or under 18) spend with their children is much higher today than in the past (BIANCHI, 2000; WATKINS et al., 1987).

Sayer et al. (2004) showed that not only mothers but also married fathers spend more time with their children today. Analyzing data from time diary surveys from the 1960s to the 1990s and using the decomposition method, they show that this change is due to both compositional (family composition) and behavioral (parenting practices) factors, but behavioral factors prevailed. Sayer et al. pointed out some possible reasons for these changes in behavior: 1) parenting today is more voluntary because of the many types of contraception 
available. Consequently, those who do become parents might be willing to spend more time with their children; and 2) safety has become a concern and, today, parental supervision and monitoring are considered indispensable. The finding that the time mothers spend with their children did not change significantly, and that fathers' time (at least that of married fathers) has increased, may indicate why children's outcomes have not changed drastically in the wake of mothers' higher employment rate.

An important topic in recent research is the relationship between family arrangements (intact, non-intact, and complex families) and children's outcomes. It is widely argued that children who experienced family disruptions have lower outcomes than children in families with two biological parents, although there is no agreement among researchers on this point, and the mechanisms and explanations are still unclear and under debate. The main explanations include i) indirect effects of family structure due to income loss and mobility (MCLANAHAN; SANDEFUR, 1997), the lack of involvement of an absent parent (usually the father) (BELLER, 2006), the limited time spent with parents (BIANCHI, 2000; SAYER et al., 2004), and women's disadvantages in terms of employment and occupational positions (BIBLARZ; RAFTERY, 1993); ii) selection effects and endogeneity or the existence of problems even before a disruption (BIBLARZ; RAFTERY, 1999); and iii) per-se family effects, such as stress and parents' motivations for investing in their children, as proposed by Biblarz and Raftery (1999).

McLanahan and Sandefur (1997) analyzed data from different national surveys and found that about half of the difference in high school dropout rates for children from single-parent families is due to loss of income. Another important explanation is the dearth of community resources; children in stepfamilies are more likely to move and single-parent families more likely to live in poor neighborhoods; thus, both feel the lack of community resources. Income might also be related to other resources, such as cultural options, because income, occupational status and education are highly correlated. We could say that class origin also plays a fundamental role in children's outcomes not only because of income differences but also because social class has an important impact on the cultural logic of childbearing (LAREAU, 2003).

In Brazil, Morais et al. (2010) analyzed whether being in a single-parent family, in contrast to being in a two-parent family, influences children's educational outcomes. Using the Grade Progression Probability method, the authors did not find statistically significant differences between children from these two types of family arrangements.

What is missing in this research in Brazil is, fundamentally, the inclusion of data on parents not living in the same household as their children and data on adults other than the parents, such as grandparents, in the household. In the United States, McLanahan and Sandefur (1997) believe that the presence of a grandmother is negative, and the presence of a stepparent is not significant because children in these arrangements do just as poorly as children in single-mother families. Unfortunately, there is no evidence of such findings in 
Brazil. It is also important to qualify the single parent, as the authors highlight, exemplified by the fact that being a widow might have a different effect from never having been married.

Beller (2006) analyzed the impact of family structure on children's occupational status and explores the lower educational outcomes of children in single-parent (usually single-mother) families. One of the factors she stresses is the importance of fathers' involvement in children's educational decisions. In another study by Biblarz and Raftery (1993), the main conclusion was that the negative impact of mother-headed households on their sons' occupational attainment is minor and entirely a function of women's disadvantaged employment and occupational positions. In a more recent text, Biblarz and Raftery (1999) presented an evolutionary psychological explanation for the differential in children's outcomes. The results showed that children from single-father families and stepfamilies have consistently shown lower occupational and educational attainment than children from two-biological-parent families as well as from single-mother families. The evolutionary parental investment theory has both statistical and change predictions that better explain the results, as it predicts that children from single-mother families will have advantages over those from single-father families because mothers have more of their reproductive investment tied up in their children than do fathers. It also predicts that stepparents will be of no advantage to children because such adults have no real incentive to raise stepchildren. Another possible explanation is the formation of new families. Manning and Smock (1999) analyzed whether having a new family impacts child visitation by fathers, and found that the arrival of new children, especially new biological children, reduces the odds of fathers' visiting their children from previous marriages.

Most studies on single parenting present policy recommendations. The main concern regarding such recommendations is the idea that marriage can represent an economic solution for single mothers and a better family arrangement for children. But this does not seem to be the best recommendation. McLanahan and Sandefur (1997) showed that children in stepfamilies have similar high-school dropout rates. Biblarz and Raftery (1999) also found that stepfamilies have weaker intergenerational relations. Beller (2006) showed that parental involvement, even if the parent does not live with the child, is what matters in terms of finishing high-school. It is also worth highlighting that the meaning of marriage is no different for poor women, as clearly documented by Edin and Kefalas (2005). However, such women might not be better off if they married men from their own communities or social class.

While many studies focus on the importance of mothers' characteristics, others give more attention to those of fathers. In response to this type of study, Beller (2009) proposed the inclusion of mothers' occupations in social mobility studies. This inclusion would indicate another positive or negative effect of mothers' employment and a reconceptualization of class background as an accumulative class resource for children. Beller (2009) highlighted the importance of including mothers' occupations in social mobility studies. She found that the models which use both parents' measures jointly are better than models that consider only one parent's class origin. Mothers' characteristics should be included not only because of their direct influence on children's outcomes but also because of their indirect effect. Lareau's 
(2003) work represents important progress in this direction, as she found that mothers draw on their work and professional skills and experiences to interfere in institutions (i.e., schools) to make sure that their children get what they need.

Using child mortality as the outcome, Breierova and Duflo (2004) analyzed how mothers' and fathers' educations influence child survival. The main conclusion is that for child mortality, women's and men's educational levels are equally important. The authors used an instrumental variable for education, one important contribution being the inclusion of fathers' education in studies of children's health and well-being, since, in most studies, only the mother's education is considered. Moreover, in the context of fathers' spending more time with children, one might suppose that fathers' education is also important for outcomes other than those related to occupation and education. Breierova and Duflo's work provides a good example of the importance of fathers' characteristics, a point that is also analyzed and discussed in Beller (2006). Thus, the challenge for future research is to consider the influence of both parents' characteristics when analyzing children's outcomes.

Last but not least, I want to highlight certain data issues in the analyses of children's outcomes. From the above discussion one can see that data concerning both parents, including a parent that may live in a different household, and data on stepparents, are crucial for reaching conclusions as to how parents' characteristics (i.e. education, occupation and time use) influence children's life outcomes, such as child mortality, education and social mobility.

Only two datasets are available in Brazil for analyzing transitions (i.e. grade progression): Pesquisa Mensal de Emprego (Monthly Employment Survey) (PME) and Pesquisa de Emprego e Desemprego (Employment and Unemployment Survey) (PED). They are not nationally representative and only allow short term analyses (maximum of one year difference from one status to the other one). This data is appropriate for comparing children's outcomes and different family arrangements (i.e. MORAIS et al., 2010). However, it is not appropriate for capturing changes when marital disruptions are present because disruptions can only be captured from these data if one of the parents stays in the same household. In this case, the previous education or occupation of the absent parent can be used. Because many divorced and remarried individuals move out, this might not be the best data to be used and results would be biased. Furthermore, the marital disruption could have occurred due to an unexpected change of occupational status or income (i.e. being unemployed) and the use of previous information would be misleading. Therefore, Brazilian statistics must be collected in which non-resident parents report their own personal data and their contribution to child support, frequency of visits, and other information. Smock and Manning (1997), using distinct data by which they could match ex-couples, found that characteristics of the non-resident parent are very important for explaining child support.

Another type of research that deserves consideration is time use analysis. Time use studies in Brazil have focused on gender differences, and no information is available on how children spend their time, especially time with their parents. There is also need for data regarding visits and time spent with the non-resident parent. 


\section{Final comments}

The model of the man as the breadwinner with a stay-at-home wife who only takes care of house and children has changed. Today's model of family includes multiple forms of families, such as childless couples, homosexual couples with and without children, greater numbers of stepfamilies, and other arrangements. Lesthaeghe (1997) highlighted that, since 1960, there has been an ideational change from viewing the child as king to a phase more centered on the adults' self-satisfaction and development. Thus, children are no longer the focus of the family. According to Cherlin (2009), marriage has taken on a different meaning. It has become individualized. In modernity, relationships are projects of the self, and everyone must have a reflexive project (GIDDENS, 1997). The main point of these arguments is that, since about the 1960s, there has been a transformation in the family that cannot be adequately translated into numbers or rates. The main change was ideational, since, today's family involves choice, options and self-development. This is in sharp contrast to traditional transitions of family formation and family dissolution (which, in the past, was usually due to death).

This change has affected many different institutions, including those in the religious and legal spheres, which have adapted the traditional discourse of individualized marriage to current social realities (CHERLIN, 2009). Although many changes were predicted for the family sphere in the face of industrialization and urbanization, many of them are far from being what one might have expected. The main expectation was the nuclearization of family, whereas what we see today is wide a variety of family arrangements. This expectation might strengthen the conclusion that the family is in trouble or in crisis (BERGSTON, 2001). Nonetheless, the family still has its special meaning and place in society and does not seem to be in danger of extinction. In this sense, the concept of the family has been widely discussed and should be open to the variety of families that we now see in society. Moreover, the debate about ongoing processes or ruptures in terms of the family is still in session.

Two other issues are discussed in this paper. The first is in regard to women, and more specifically, to mothers in the labor market (income, job opportunities, and so on). Women and the family as a group are coping with the greater presence of women in the labor force. One central question is: What are the differences among married, childless, and single men and women? The second issue has to do with the effects of changes in the family on children's outcomes, because they are now more likely to experience family disruption and live with stepparents (changes in the family structure) and, in addition, of course, mothers are spending less time at home and more time working.

The changes that have taken place in the family have affected the concerns of the academic world. Today, for example, there is greater interest in studying the consequences of these changes in women's and children's outcomes. For this reason, the data collection and the theoretical framework that are used in family research deserve close attention. 
Although many improvements have been made, the field of family studies continues with many of the lacunas already pointed out by earlier authors. Goldani (1984), for example, concludes that the lack of appropriate data for family studies not only compromises the use of available techniques; it also impairs our knowledge about an important institution in society and how it is changing in the present day. Lazo (2002) highlights the need for data on nuptiality on the PNAD, because marital status was removed from this survey in 1996 and returned only in 2009. Even when information about nuptiality was treated (between 1992 and 1995), it was incomplete, because the only variable was marital status. Another issue is the concern as to how to expand and apply the concept of family. Goldani (1993, p.79) concludes that the data available offer elements for analysis of domestic units, but only rarely can the process that originated the diversity in family arrangements be reconstructed.

Reinforcing previous research, I suggest that there is need to include different types of information in data collection projects: i) Non-residential parents should be included in the sample in time use surveys. Time use research in Brazil has focused mainly on differences between women and men but it is also important to introduce data about children and how they spend their time with their parents; ii) In social mobility surveys, data on mothers' occupations should be included, as well as non-resident fathers' occupations, information about the reason for family disruptions, if any, and the year; iii) In household surveys, information about the non-resident parent should be obtained and other relatives living in the household should be listed; iv) There is need for longitudinal data because when it is lacking it becomes very difficult to do research on decision-making processes, such as motherhood and marriage timing, marital history and transitions, cohabitation before marriage, the influence of cohabitation, and previous marriages and divorces; v) Another type of data that should be explored in greater detail is ideational information (in Section 2.2 I suggest the use of World Value Survey); these aspects would be important for analyzing how ideas change over time and in different groups, (i.e. socioeconomic, racial, etc.); vi) A different type of study that has not been explored in demography but could be very helpful for researchers in the field of family is experimental research; it is important not only for studying normative aspects of female labor force participation, as Correll et al. (2007) have done, but also for analyzing behavioral aspects in demography, such as altruism among family members, decisions on fertility, marital choices, and other aspects. These are just a few ideas for improving data collection in a society with rising divorce rates, the increased time that fathers spend with their children, and greater numbers of single-parent families.

In terms of additions to and revisions of theoretical frameworks, I have referred above to three important contributions for future research that would seem to be in order. The first is to study how people make decisions in the family sphere, going beyond the purely economic aspect of social action. As Bilac (1995) has argued, there are various types of social action and rationalities. The second contribution is to revise the SDT in terms of its legitimacy and include migration and mortality in its framework. More specifically, this instrument should show how both migration and mortally, as well as changes in fertility can influence the family. 
There is a discrepancy between the frequent recognition that lower mortality has an impact on family composition, and the SDT's approach, which focuses on decline in fertility. Bilac (1995) also points out the importance of the migration of relatives when analyzing family size, so it must be clear just who the members of the household are. Depending on the period one is analyzing, it is very common for a variety of relatives to be living in the same household, especially in urban areas, since this is how many migrants from rural areas integrate into urban life. Another line of research that emphasizes the importance of migration is based on Rosenfeld's (2005) hypothesis, which states that higher geographical mobility, as a consequence of higher education among young people, is one of the reasons for increased interracial and homosexual unions. The third point is the need for greater integration between demographic studies, gender studies and feminist perspectives (see, for example, WATKINS, 1993; MACKINSSON, 1995; OLIVEIRA, 1996; BILAC, 1995, 2006; PRESSER, 1997; RILEY; MCCARTHY, 2006). Some hold that there has been little discussion on gender issues, but this stance is somewhat strange, because demography has produced numerous studies on women, and most of the models focus on a single sex (female), not only in fertility studies, but also in projections. However, very few studies consider gender as a social and cultural production, and there are few topics related to it. As highlighted by Riley and McCarthy (2003) a distinction should be made between studies that include women and studies that examine the broader implications of gender.

Last but not least, I suggest four topics that I feel should be explored more intensely in Brazil. First, there should be more discussions about cohabitation, marriage history and transition from one marital status to another (i.e. cohabitation, marriage, divorce, and remarriage). The analyses should focus not only on identifying changes in rates and proportions over time, but also on differences between groups (i.e. class, age, and race) as the result of new family structures. Explanations about the process of family formation and the choice between marriage and cohabitation, for example, are also necessary. Second, the changes in family structure and family formation have transformed the issue of women in the labor force from a women's issue into a family issue. Therefore, studies about labor market outcomes must consider women's and men's marital statuses and parenthood. Two examples of this type of research in Brazil are Muniz and Rios-Neto (2004), and Kassouf and Senauer (1996). Both focus on income, but little is still known about other outcomes, such as job opportunities, hiring preferences, promotions, and job evaluation. The third topic that deserves more attention is the relationship between assortative mating and children's outcomes, or, in other words, the inclusion of characteristics of both parents when analyzing children's outcomes. Characteristics of both parents are also important for analyzing of social mobility, educational achievement studies, and time use, especially on the question of how much time parents spend with their children and what they do together. Lastly, there is need in Brazil for analyses on how fertility and marital stability are related, to what extent the number of children influences marital instability (THORNTON, 1977), and how marital dissolution impacts fertility levels (THORNTON, 1978). 
Finally, I want to highlight that all topics discussed in this text deserve specific papers. It was not my objective to fully approach them, but to raise just a few of the many questions and issues that should be part of future research on the family.

\section{References}

ALVES, J. E. D; CAVENAGHI, S. M.; BARROS, L. F. W. A família DINC no Brasil: algumas características sóciodemográficas. Rio de Janeiro: Escola Nacional de Ciências Estatísticas. IBGE, 2010 (Textos para discussão, n. 30). Available at: 〈http://www.ence.ibge.gov.br/c/document_library/get_file?uuid=0e7dab2c-35954e18-b2ec-62f342157f5a\&groupld=37690208>.

BECKER, G. S.; LANDES, E. M.; MICHAEL, R. An economic analysis of marital instability. The Journal of Political Economy, v. 85, n.6, p. 1141-1188, 1977.

BELLER, E. Re-conceptualizing 'parent' education in predicting children's educational attainment: how attention to the non-residential parent's education is key to understanding the lower educational outcomes of children raised in single parent families. In: ANNUAL MEETING OF THE AMERICAN SOCIOLOGICAL ASSOCIATION. Quebec, Montreal Convention Center, 2006.

BELLER, E. Bringing intergenerational social mobility research into the twenty-first century: why mothers matter. American Sociological Review, v. 74, n. 4, p. 507-528, 2009.

BENGTSON, V. L. Beyond the nuclear family: the increasing importance of multigenerational bonds. Journal of Marriage and Family, v. 63, n. 1, p. 1-16, 2001.

BERQUÓ, E. A família no século XXI: um enfoque demográfico. Revista Brasileira de Estudos de População, v. 6, n. 2, p. 1-16, 1989.

BERQUÓ, E.; OLIVEIRA, M. C. Casamento em tempos de crise. Revista Brasileira de Estudos de População, v. 9, n. 2, p. 155-167, 1992.

BIANCHI, S. M. Maternal employment and time with children: dramatic change or surprising continuity. Demography, v. 37, n. 4, p. 401-414, 2000.

BIBLARZ, T. J.; RAFTERY, A. R. The effects of family disruption on social mobility. American Sociological Review, v. 58, n. 1, p. 97-109, 1993.

BIBLARZ, T. J.; RAFTERY, A. R. Family structure, educational attainment, and socioeconomic success: rethinking the 'Pathology of Matriarchy'. American Journal of Sociology, v. 105, n. 2, p. 321-65, 1999.

BILAC, E. D. Família: algumas inquietações. In: CARVALHO, M. C. B. A família contemporânea em debate. São Paulo: Editora da PUC-SP, 1995.

Plus ça change (resenha). Revista Brasileira de Estudos de População, v. 21, n. 1, p. 161-166, 2004.

Gênero, vulnerabilidade das famílias e capital social: algumas reflexões. In: CUHA, J. M. P. (Org.). Novas metrópoles paulistas: população, vulnerabilidade e segregação. Campinas: Nepo/ Unicamp, 2006, p.51-65.

BLOSSFELD, H.; HUININK, J. Human capital investments or norms of role transition? how women's schooling and career affect the process of family formation. The American Journal of Sociology, v. 97, n. 1, p. 143-168, 1991.

BONGAARTS, J. Household size and composition in the developing world in the 1990s. Population Studies, v. 55, n. 3, p. 263-279, 2001.

BREIROVA, L.; DUFLO, E. The impact of education on fertility and child mortality: do fathers really 
matter less than mothers? National Bureau of Economic Research, 2004 (Working paper. n. 10513).

BUMPASS, L. L. What's happening to the family? Interactions between demographic and institutional change. Demography, v. 27, n. 4, p. 483-498, 1990.

CALDWELL, J. C. Toward a restatement of demographic transition theory. Population and Development Review, v. 2, n. 3/4, p. 321-366, 1976.

CAMARANO, A. L.; MELO, J. L.; KANSO, S. Famílias brasileiras: mudanças e continuidades. In: CASTRO, J. A.; RIBEIRO, J. A. C. Situação social brasileira 2007. Ipea, 2009.

CARVALHO, M. J. S.; MACHADO, J. B. Análise dos usos do tempo entre crianças acerca das relações de gênero e de classe social. Currículo sem Fronteiras, v. 6, n. 1, p. 70-81, 2006.

CASPER, L. M.; BIANCHI, S. M. Continuity and change in the American family. Thousand Oaks, CA: Sage, 2002.

CLIQUET, R. L. The second demographic transition: fact or fiction? Council of Europe. Population Studies, n. 23, Strasbourg, 1991.

COLEMAN, D. Why we don't have to believe without doubting in the 'Second Demographic Transition'. Some agnostic comments. Contribution to a debate on the Second Demographic Transition, European Population Conference, Warsaw, August 2003.

. Why we don't believe without doubting in the "Second Demographic Transition" - some agnostic comments. Vienna Yearbook of Population Research. 2004, p.11-24.

CORRELL, S. J.; BENARD, S.; PAIK, I. Getting a job: is there a motherhood penalty? American Journal of Sociology, v. 112, n. 5, p. 1297-1339, 2007.

COSTA, C. S. Uniões informais no Brasil em 2000: uma análise sob a ótica da mulher. Dissertação (Mestrado em Demografia) - Centro de Desenvolvimento e Planejamento Regional, Universidade Federal de Minas Gerais, 2004.

COX, D. Biological basics and the economics of the family. Journal of Economic Perspectives, v. 21, n. 2, p. 91-108, 2007.

DURHAM, E. Família e casamento. In: III ENCONTRO NACIONAL DE ESTUDOS POPULACIONAIS. Anais... Abep, 1982.

DUFLO, E. Grandmothers and granddaughters: old age pension and intra-household allocation in South Africa. The World Bank Economic Review, v. 17, n. 1, p. 1-25, 2003.

EDIN, K.; KEFALAS, M. Promises I can keep: why poor women put motherhood before marriage. Berkeley and Los Angeles: University of California Press, 2005.

FISCHER, C. S.; HOUT, M. The family in trouble? Since when? For whom? In: TIPTON, S. M.; WITTE JR., J. (Eds.). The family transformed: religion, values, and society in American life. Washington DC: Georgetown University Press, 2005.

FONTOURA, N.; PINHEIRO, L.; GALIZA, M.; VASCONCELOS, M. Pesquisas de uso do tempo no Brasil: contribuições para a formulação de políticas de conciliação entre trabalho, família e vida pessoal.

Revista Econômica, v12, n 1, 2010.

GOLDANI, A. M. A demografia "formal" da família. In: IV ENCONTRO NACIONAL DE ESTUDOS DE POPULAÇÃO. Anais... Abep, 1984.

Womens' transition: the intersection of female life course, family and demographic transition in twentieth century Brazil. Tese (Doutorado) - University of Texas at Austin, 1989.

As famílias no Brasil contemporâneo e o mito da desestruturação. Cadernos Pagu. De 
Trajetórias e Sentimentos, Campinas, n. 1, 1993.

Reinventar políticas para familias reinventadas: entre la "realidad" brasileña y la utopía. In: REUNIÓN DE EXPERTOR "POLÍTICAS HACIA LAS FAMILIAS, PROTECCIÓN Y INCLUSIÓN SOCIOALES." Cepal, 28 y 29 de junio 2005.

GOLDSCHEIDER, F. K.; BURES, R. M. The racial crossover in family complexity in the United States. Demography, v. 40, n. 3, p. 569-587, 2003.

HOCHSCHILD, A.; MACHUNG, A. The second shift. New York: Avon Books Press, 1990.

KASSOUF, A. L.; SENAUER, B. Direct and indirect effects of parental education on malnutrition among children in Brazil: a full income approach. Economic Development and Cultural Change, v. 44, n. 4, p. 817-838, 1996.

LAREAU, A. Unequal childhoods: class, race, and family life. University of California Press, 2003.

LAZO, A. C. G. V. Avaliação das histórias de uniões do suplemento de fecundidade da PNAD-84 do Estado de São Paulo. In: SEMINÁRIO DE AVALIAÇÕES DAS PNADS DAS DÉCADAS DE 80.1988.

. Nupcialidade em São Paulo: um estudo por corte e coorte. Tese (Doutorado) - Campinas, Universidade de Campinas - Unicamp, 1991.

ก. 889).

Nupcialidade nas PNADS-90: um tema em extinção? Ipea, 2002 (Texto para discussão,

LAZO, A. C. G. V.; MORAES, J. R. As uniões consensuais no Estado do Rio de Janeiro em 2000: um estudo utilizando regressão logística. In: ENCONTRO NACIONAL DE ESTUDOS POPULACIONAIS. Anais... Caxambu, Abep, 2004. Available at: 〈http://www.abep.org.br/usuario/GerenciaNavegacao. php?caderno_id=437\&nivel=2>.

LESTHAEGHE, R. Imre Lakatos' views on theory development: applications to the field of fertility theories. Brussels, IPD, VUB, 1997 (Working paper, 1997-1).

Second demographic transition. In: RITZER, G. (Ed.). Encyclopedia of Sociology. Blackwell, 2007, p. 4.123-4.127.

LLOYD, C. B.; DESAI, S. Children's living arrangements in developing countries. Population Research and Policy Review, n. 11, v.3, p. 193-216, 1992.

MACKINNON, A. Were women present at the demographic transition? Questions from a feminist historian to historical demographers. Gender \& History, v. 7, n. 2, p.222-240, 1995.

MANNING, W. D.; LANDALE, N. S. Racial and ethnic differences in the role of cohabitation in premarital childbearing. Journal of Marriage and Family, v. 58, n. 1, p. 63-77, 1996.

MANNING, W. D.; SMOCK, P. J. New families and non resident father-child visitation. Social Forces, v. 78, n. 1, p. 87-116, 1999.

MARCONDES, G. S. Refazendo famílias: trajetórias familiares de homens recasados. Tese (Doutorado) - Campinas, Universidade de Campinas - Unicamp, 2008.

MARE, R. A multigenerational view of inequality. Demography, v. 48, n. 1, p. 1-23, 2011.

MATTINGLY, M. J.; BIANCHI, S. M. Gender differences in the quantity and quality of free time: the U.S. experience. Social Forces, v. 81, n. 3, p. 999-1030, 2003.

MCLANAHAN, S.; SANDEFUR, G. Growing-up with a single parent: what hurts, what helps. Harvard University Press, 1997.

MIRANDA-RIBEIRO, P. Começar de novo: um estudo comparativo do descasamento e recasamento. 
Dissertação (Mestrado em Demografia) - Belo Horizonte, Centro de Desenvolvimento e Planejamento Regional, Universidade Federal de Minas Gerais, 1993.

MORAIS, T. de A.; GUIMARÃES, R. R.; RIOS-NETO, E. 0 efeito da estrutura familiar sobre a estratificação educacional no Brasil: evidências com base na probabilidade de progressão por série entre 1986 e 2008. Belo Horizonte: UFMG/Cedeplar, 2010. (Textos para discussão, n. 409). Available at: 〈http:// www.cedeplar.ufmg.br/pesquisas/td/TD\%20409.pdf〉.

MUNIZ, J.; RIOS-NETO, E. Marriage premium in Brazil. In: POPULATION AMERICAN ASSOCIATION ANNUAL MEETING. Boston, PAA, 2004. Available at: <http://paa2004.princeton.edu/download. asp?submissionld $=41576$ >

OLIVEIRA, M. C. A família brasileira no limiar do ano 2000. Estudos Feministas, v. 4, n.1, p. 55-63, 1996.

OLIVEIRA, R. V. C.; MAGALHÃES, M. S.; LAZO, A. C. G. V. Modelos de Goodman: perfis das uniões pela cor dos casais. In: XV ENCONTRO NACIONAL DE ESTUDOS POPULACIONAIS. Anais... Caxambu: Abeb, 2006. Available at: 〈http://www.abep.nepo.unicamp.br/encontro2006/docspdf/ABEP2006_309.pdf〉.

PRESSER, H. B. Demography, feminism, and the science-policy nexus. Population and Development Review, v. 23, n. 2, p. 295-331, 1997.

RIBEIRO, E. Valores pós-materialistas e adesão normativa à democracia entre os brasileiros. Revista Debates, v. 2, n. 2, p. 103-133, 2008.

Mudança de valores e tolerância entre os brasileiros. Mediações, v. 15, n. 1, p. 220240, 2010.

RIBEIRO, E.; BORBA, J. Participação e pós-materialismo na América Latina. Opinião Pública, v. 16, n. 1, p. 28-64, 2010.

RILEY, N.; MCCARTHY, J. Feminist demography. In: RILEY, N.; MCCARTHY, J. Demography in the age of the postmodern. United Kingdom: Cambridge University Press, 2003 (Series New Perspectives on Anthropological and Social Demography).

ROSENFELD, M. J. The age of independence: interracial unions, same-sex unions, and the changing American family. Harvard University Press, 2007.

SAYER, L. O.; BIANCHI, S. M.; ROBINSON, J. Are parents investing less in children? Trends in mothers' and fathers' time with children. American Journal of Sociology, v. 110, n. 1, p. 1-43, 2004.

SEWELL, W.; HAUSER, R. M.; WOLF, W. C. Sex, schooling and occupational status. American Journal of Sociology, v. 86, n. 3, p. 551-583, 1980.

SMOCK, P. J.; MANNING, W. D. Non resident parent's characteristics and child support. Journal of Marriage and Family, v. 59, n. 4, p. 798-808, 1997.

THERBORN, G. Sexo e poder: a família no mundo 1900-2000. Tradução de Elisabete Doria Bilac. São Paulo: Editora Contexto, 2006.

THORNTON. A. Children and marital instability. Journal of Marriage and Family, v. 39, n. 3, p. 531-540, 1977.

Marital dissolution, remarriage and childbearing. Demography, v. 15, n. 3, p. 361-380, 1978. Changing attitudes toward family issues in the United States. Journal of Marriage and

Family, v.5 1, n. 4, p. 873-893, 1989.

TILLMAN, K. H.; NAM, C. B. Family structure outcomes of alternative family definitions. Population Research and Policy Review, v. 27, n. 3, p. 367-384, 2008.

TOMÁS, M. C. 0 ingresso dos jovens no mercado de trabalho: uma análise das regiões metropolitanas 
brasileiras nas últimas décadas. Dissertação (Mestrado em Demografia) - Belo Horizonte, Centro de Desenvolvimento e Planejamento Regional, Universidade Federal de Minas Gerais, 2007.

TOMÁS, M. C.; OLIVEIRA, A. M. H.; RIOS-NETO, E. Adiamento do ingresso no mercado de trabalho sob o enfoque demográfico: uma análise das regiões metropolitanas brasileiras. Revista Brasileira de Estudos de População, v. 25, n. 1, p. 91-107, 2008.

VIEIRA, J. M.. Transição para a vida adulta no Brasil: análise comparada entre 1970 e 2000. Revista Brasileira de Estudos de População, v. 25, n. 1, p. 27-48, 2008.

WATKINS, S.; MENKEN, J.; BONGAARTS, J. Demographic foundations of family change. American Sociological Review, v. 52, n. 3, p. 346-358, 1987.

WATKINS, S. If all we knew about women was what we read in demography, what would we know? Demography, v. 30, n. 4, p. 551-577, 1993.

\section{Resumo}

\section{Revendo estudos sobre famílias: um breve comentário sobre tópicos selecionados}

Em face das mudanças na esfera da família e das preocupações acadêmicas ao se analisarem estas mudanças, a coleta de dados e as abordagens teóricas usadas em pesquisas sobre família merecem atenção. Neste artigo, são revisadas brevemente algumas importantes contribuições internacionais na área da família e apontados alguns desafios e perguntas ainda sem respostas para futuras pesquisas no Brasil. Os três assuntos principais são: mudanças no conceito de família; retorno no mercado de trabalho (salário, oportunidades de trabalho, preferências por contratação) de mulheres e, principalmente, mães e mais especificamente a transformação da discussão de mulheres trabalhadoras para famílias trabalhadoras; e a influência dos dois primeiros tópicos nos resultados das crianças. Ao final do artigo, reforçam-se estudos anteriores, com sugestões pontuais para a coleta de dados. Do lado teórico, é destacada a importância de três abordagens: não é suficiente considerar os aspectos econômicos da tomada de decisão na esfera da família; há uma necessidade de se revisar a teoria da Segunda Transição Demográfica, especialmente no que concerne à migração e à mortalidade e suas relações com a família; e a necessidade de uma integração maior entre estudos demográficos, gêneros e teorias feministas.

Palavras-chave: Mudanças na família. Resultados das crianças. Mulheres e famílias trabalhadoras.

\section{Resumen}

\section{Revisando Estudios familiares: un breve comentario sobre temas seleccionados}

Frente a los cambios en las familias y a las preocupaciones académicas presentes en el estudio de tales cambios, merecen atención la recogida de datos y la estructura teórica utilizadas en las investigaciones sobre familias. El propósito de este artículo es presentar algunas contribuciones internacionales importantes para el ámbito de los estudios de la familia y señalar algunos desafíos y preguntas todavía sin respuesta para una futura investigación en Brasil. Los tres temas principales serían los siguientes: cambios en el concepto de familia; perspectivas femeninas, sobre todo las de las madres de familia, en el mercado laboral (ingresos, oportunidades de trabajo, preferencias en la contratación, etc.), y de forma más específica, la discusión sobre la mujer trabajadora, cambiando su foco para el de la familia trabajadora; y la influencia de los temas arriba mencionados sobre las perspectivas de los niños. Al final 
del artículo refuerzo algunas investigaciones anteriores al sugerir mejoras en proyectos de recogida de datos. Por la lado teórico, subrayo la importancia de tres puntos: no basta considerar el aspecto económico de la acción social sobre cómo las personas toman decisiones en el esfera familiar; es necesario revisar el enfoque de la Segunda Transición Demográfica, especialmente en lo que concierne a la migración y a la mortalidad y su relación con la familia; también es necesario integrar más los estudios demográficos, el género y las perspectivas feministas.

Palabras clave: Cambios familiares. Resultados de los niños. Mujeres y familias trabajadoras.

Recebido para publicação em 30/08/2011

Aceito para publicação em 18/11/2011 